\title{
Modeling impacts to agricultural revenue and government service costs from urban growth
}

\author{
Nathaniel E. Roth ${ }^{\mathrm{a} *}$, James H. Thorne ${ }^{\mathrm{b}}$, Robert A. Johnston ${ }^{\mathrm{c}}$, and James F. Quinn ${ }^{\mathrm{d}}$ \\ Environmental Science \& Policy, University of California, Davis \\ Michael C. McCoy ${ }^{\mathrm{e}}$ \\ Urban Land Use and Transportation Center, University of California, Davis
}

Submitted 5 August 2011 / Revised 8 December 2011, 13 March 2012, 4 May 2012 / Accepted 8 May 2012 /

Published online 29 August 2012

Citation: Roth, N. E., Thorne, J. H., Johnston, R. A, Quinn, J. F, \& McCoy, M. C. (2012). Modeling impacts to agricultural revenue and government service costs from urban growth. Journal of Agriculture, Food Systems, and Community Development, 2(4), 43-62. http://dx.doi.org/10.5304/jafscd.2012.024.008

Copyright (C) 2012 by New Leaf Associates, Inc.

a* Corresponding author: Nathaniel E. Roth, Department of Environmental Science and Policy, University of California; 1 Shields Avenue, Davis, California 95616 USA; +1-530-7546212; neroth@ucdavis.edu

b James H. Thorne, Department of Environmental Science and Policy, University of California, Davis; 1 Shields Avenue; Davis, California 95616 USA: +1-530-752-4389;

jhthorne@,ucdavis.edu

${ }^{c}$ Robert A. Johnston, Department of Environmental Science and Policy, University of California, Davis; 1 Shields Avenue; Davis, California 95616 USA; +1-530-559-0032; rajohnston@ucdavis.edu

d James F. Quinn, Department of Environmental Science and Policy, University of California, Davis; 1 Shields Avenue; Davis, California 95616 USA; +1-530-752-8027; jfquinn@ucdavis.edu

e Michael C. McCoy, Urban Land Use and Transportation Center; Department of Environmental Science and Policy, University of California, Davis; 1 Shields Avenue; Davis, California 95616 USA; +1-530-754-9171; mcmccoy@ucdavis.edu

\begin{abstract}
Urban expansion in rural areas may impact agricultural revenues and the burden of service provision on local governments. Spatially explicit urban growth models shed light on the consequences of such land use decisions. The San Joaquin Valley, an important agricultural region of California, will double in population by 2050 . Using this region as an example, we modeled the spatial patterns of urban growth under seven policy scenarios and calculated potential loss of annual agricultural revenue from each. We also measured the distance from existing urban areas to new development in order to develop scenario-specific indicators of the cost to local governments for providing urban services such as sewer, water, roads, police and fire protection.

As with all modeling exercises, an understanding of the strengths and weaknesses of the model being applied is essential for interpretation. The modeling applied here is not a full economic mode, but instead applies simple processes using frequently available data to estimate the farmgate
\end{abstract}


revenue lost to agricultural land conversion and to represent service costs. Crop replacement, relocation, and the conversion of unfarmed lands to cropland, among other factors, are not considered. Other effects either positive or negative that may result from the growth patterns have not been analyzed.

The unconstrained growth scenario (Status Quo) consumed the most land and had the greatest impact on agricultural revenue. Compact development had the least impact on agricultural revenue and the shortest distances to new development. Other forms of agricultural land protection and growth management scenarios fell short of the agricultural revenue savings and service cost reductions provided by compact development.

\section{Keywords}

agriculture, farmland protection, transportation infrastructure, urban growth, urban growth model, urban services

\section{Introduction}

\section{Study Location: San Joaquin Valley}

Many of the world's cities were established near trade routes and fertile agricultural lands. As these cities continue to expand today, they almost always do so at the expense of fertile and productive agricultural land. With an additional 1.75 billion people projected to share the Earth by 2030 (McDonald, 2008), urban growth and the conversion of agricultural land to other uses are on going concerns to global food supply. Approaches to address these phenomena vary by region (Alterman, 1997; Fazal, 2001; Heimlich \& Anderson, 2001). In many cases the new urban growth occupies space that was previously natural, agricultural, or grazing lands (Ackerman, 1999; Bengston, Fletcher \& Nelson et al., 2004; Bengston \& Youn, 2006; Brabec \& Smith, 2002). This is especially true of the principal cities of one of the major agricultural centers in the U.S., the San Joaquin Valley, California. The expanding urban footprint of these cities damages their agricultural foundation and raises the question of the role that urban space plays in the agricultural economy.
In the United States, despite recent interest in compact growth, much new housing construction still occurs on large lots, with new residents relying on the expansion of transportation and utilities infrastructure to support increasingly dispersed lifestyles (Davis, Nelson \& Dueker, 1994; Ewing 1997). While average lot sizes decreased nationally over the past few decades (Sarkar, 2011, p. 2), the population density of new growth is not trending upwards (U.S. Census Bureau, 2000a, 2000b, 2010; U.S. Department of Agriculture, 2009a, p. 31).

Historically, urban growth often has occurred at the direct expense of agricultural land, removing it from active production. This loss of agricultural productivity can deprive the local region of significant sources of base income and employment (Bradshaw \& Muller, 1998). The United States, Western Europe, and China have implemented policies at various levels to counteract urban sprawl, with varying levels of success (Bengston et al., 2004; Lin \& Ho, 2005; Richardson \& Bae, 2004, p.6; Tan, Beckmann, van den Berg, \& Qu, 2009).

In areas such as the San Joaquin Valley, lowdensity "rural" residential growth (lots greater than 1 acre, or .4047 hectare, per dwelling) adjacent to cities can impact agricultural regions (American Farmland Trust, 2007). Rural residences deplete agricultural production potential at a greater rate per capita than city growth, while frequently requiring many urban services such as electricity, water, civil services (police, fire, garbage), and transportation infrastructure (Carruthers \& Ulfarsson, 2003). These sprawling development patterns are difficult to define formally and cannot easily be identified by a single criterion. Several studies have attempted to classify sprawl based on a suite of criteria including density, pattern, and rate of growth (Brueckner, 2000; Burchell, 2002; Ewing, Pendall, \& Chen, 2003; Davis \& Schaub, 2005). Here we define sprawl as a pattern of lowdensity fewer than 4 dwelling units (du) per acre, or 12.3 du per hectare) residential development. Regardless of the exact definition of sprawl applied, the consumption of large amounts of land to provide developed space for a growing population is a hallmark of much recent American suburban and exurban growth. 
Urban expansion onto agricultural land has two potential impacts examined in this paper: a loss of crop revenue due to residential development (Bradshaw \& Muller, 1998; Carruthers \& Ulfarsson, 2003) and an increase in the cost of providing urban services per housing unit if units are set far apart (Carruthers \& Ulfarsson, 2003).

Accurate regional assessment of these costs is challenging. However, outputs from spatial modeling of urban growth can help identify impacted areas, permitting analysis of the associated costs for servicing urban growth (Burchell, 2002) and of associated agricultural revenue losses (Thomas \& Howell, 2003). Spatial modeling of projected urban growth can also provide a framework for comparing how impacts and costs may vary between different growth policy scenarios. Impacts that can be estimated include area of land consumed, growth of water and sewer infrastructure, local road infrastructure, public service costs, and land development costs (Burchell, 2002). Beyond these direct urban effects are the many potential effects generated by land conversion, including those to the environmental integrity of the region (Johnson, 2001) and the potential costs of displacement of productive land uses (e.g., agriculture). Additionally, the opportunity cost of future planning options in a landscape that has been subdivided among multiple owners may be substantial. There may be benefits to society from an urban sprawl development pattern, such as lower housing costs at larger distances from urban centers, but there is no clear evidence that the benefits are real, significant, and cannot be achieved in other ways (Burchell, 2002).

Many authors have studied the impacts of urban development on agricultural lands. Nelson (1992) found that urban growth boundaries decreased agricultural land values under Oregon's urban growth laws by forestalling urban conversion. In other words, an urban growth boundary reduced the speculative value of land for development outside the growth boundary. Nelson also found that the likelihood that the land will be converted to urban use heavily influences the choice of crop type planted near urban areas. Although "right to farm" laws may protect his or her legal rights to farm, a farmer may choose not to plant an orchard if he or she expects that the land will be developed in the near future because of the perceived risk of harassment and lawsuits over noisy, odorous, or chemical farming practices and the substantial length of time needed to recoup the investment. California has a "no overspray" law that enables rural residents to challenge aerial spraying practices in court (State of California, 2008a). This means residential units in rural areas impact not just the land they are built on, but also nearby land uses. Brueckner (2000) discussed the economic process that results in the conversion of agricultural land to urban. If all externalities are considered, conventional economic models suggest that the highest and best land use should take precedence. Unfortunately, as Brueckner notes, this incorrectly assumes that all of the benefits of the agricultural land are being fully considered. Bradshaw and Muller (1998) identify how development patterns can impact areas of potentially highvalue agricultural soils based on the California Urban Futures Model (Landis, 1994), but do not attempt to forecast effects on either specific crops or revenue. In the San Joaquin Valley, market values of croplands can be estimated from published county agricultural commissioners' reports, which provide the total revenue and number of acres per crop type by county.

This study used outputs from spatially explicit urban growth models to rank potential urban service costs and quantify a snapshot of agricultural production loss under seven urban growth policy scenarios for the San Joaquin Valley (SJV). The $\mathrm{SJV}$ is home to eight counties covering 16,600 square miles (43,000 square $\mathrm{km})$. The region is integrally tied to three major California metropolitan areas: Sacramento to the north, the San Francisco Bay area to the west, and the Los Angeles region to the south. The SJV is undergoing urbanization and rural sprawl, and, as one of the United States' most agriculturally productive regions and a major source of numerous specialty crops, the growth has significant implications for its local agricultural economy and larger-scale U.S. food markets. In particular, specialty crops such as fruits and nuts provide more than 10 percent of the jobs in the SJV, more than 5 percent of the total income in multiple counties within it (Hamilton, 
2004), and all eight of the counties are in the top 20 nationally by value of crops (U.S. Department of Agriculture, 2009b).

Several previous efforts to model urban growth have covered the San Joaquin Valley. Theobald (2001) covered the region as part of a national effort, Landis (1994) as part of a series of statewide efforts, and Dietzel, Herold, Hemphill, and Clarke (2005) as a regional effort. Bradshaw and Muller (1998) built on Landis's modeling to consider the possible loss of agricultural acreages under two different growth scenarios (low-density sprawl and compact high-density development) under sponsorship of the American Farmland Trust, but did not publish the likely impacts to agricultural revenue. However, the American Farmland Trust released a report that extended the analysis of the land use modeling through an economic analysis to include farmgate revenue, multiplier effects, and public service costs, finding that low-density growth had a greater effect on farm revenue and public service costs than high-density development (American Farmland Trust, 1995).

In 2005, California Governor Schwarzenegger established the Governor's Partnership for the San Joaquin Valley to assess expected impacts from population growth and to propose solutions to mitigate its negative effects (Schwarzenegger, 2005). Official forecasts predict that the population in the SJV will increase from 3.5 to 8 million by 2050 (California Department of Finance, 2004). Many county and regional planning processes are required by law to address these forecasts, so the models described here adopt the Department of Finance figures. The Governor's Partnership established the Land Use, Housing and Agriculture (LUHA) working group to assess the state of the SJV's land use and suggest future growth policies. The LUHA consists of public and private planners, real estate developers, state and federal land and resource managers, state and federal environmental regulators, environmental nongovernmental organization (NGO) officers, business advocates, and members of the region's farming industry. At LUHA's request, we modeled selected urban growth scenarios defined by the working group to provide a multicounty visualization of the spatial urban footprints resulting from seven broad land use policies. We used UPlan (Johnston, Shabazian, \& Gao, 2003), a rule-based, spatially explicit urban growth model, to develop the urban growth projections, then assessed the outputs in terms of their relative costs for service provision and impacts on agricultural production.

\section{Spatial Modeling of Growth Footprints}

Urban Growth Models (UGMs) have the capacity to project spatial simulations of future urban growth. Varying GIS-based approaches have been used to project future land use, including expert panels, statistical projections, rule-based models, and economically driven models (Johnston et al., 2003). Expert panel modeling relies on experts' experience and assumes that the panel is able to accurately predict growth patterns. Statistical projections forecast growth based on trends, often estimated by regression, from past growth patterns, and can include cellular automata or resource and accessibility based decision models (Clarke \& Gaydos, 1998; Landis, 1994). Rule-based models forecast growth based on a series of rules defining what attracts growth to a location (Johnston et al., 2003). Economic models represent production and consumption of all goods and services, including travel and floor space, as well as all trade (Abraham \& Hunt, 2003), and predict growth where future demand for expanded facilities and services will be highest. Each model type has advantages and disadvantages. Economic models have the potential to be the most accurate and predict detailed income and employment outcomes that are important to planners, but they require extensive data assembly and a very large investment in calibration. Regression and choice models are less data-intensive but also require calibration based on past land use data. Rule-based models can be less data-intensive than regression or economic forecast models, but calibration is either not possible or requires the creation of many small area corrections with questionable applicability to future predictions (Gao \& Walker, 2005).

This study used UPlan to represent growth patterns under various scenarios. We used it partially because it is already in use in the SJV, and is familiar to regional policy-makers. UPlan is suitable for rapid scenario-based modeling because of the 
ease with which the data sets can be configured, low computational demands, and the transparency of its assumptions and algorithms to planners and policy-makers. UPlan has been used to evaluate the wildfire risks to future urban growth (Byrd et al.,Rissman, \& Merenlender, 2009), assess the impacts of different growth policies on natural resources (Beardsley, Thorne, Roth, Gao, \& McCoy, 2009), effects on conservation connectivity (Huber, Thorne, Roth, \& McCoy, 2011), has been adapted to calculate greenhouse gas contributions from new urban growth (Johnston Roth, \& Bjorkman, 2009), and to evaluate the effectiveness of land use scenarios in reducing vehicle miles travelled (Niemeier, Bai, \& Handy, 2011). UPlan was calibrated for the Philadelphia area (Walker, Gao, \& Johnston, 2007) and is widely used in California by county governments (by at least 24 counties) as planning support for zoning decisions (Johnston, McCoy, Kirn, \& Fell, 2004).

In this study we relied on baseline urban growth trends (population growth rate, household size, workers per household, proportions of urban growth by land use type, land consumption per household, and floor space per worker) to create a conceptual Status Quo growth scenario that corresponds to the "no change" scenarios in standard environmental impact reporting and from which relative differences between other policy scenarios can be measured by modifying the baseline trends in a controlled manner. We used UPlan's spatial outputs to compare relative urban service costs and estimate short-term agricultural production losses under seven urban growth scenarios for the SJV.

\section{Methods}

UPlan uses projected population growth and existing infrastructure to assign new urban growth to seven land use categories: three employment categories (industrial, commercial high-density, and commercial low-density) and four residential density classes (residential high-density, residential medium, residential low, and residential very-low). All growth allocation was based on four factors. First, the demand for space in each land use type was calculated based on how much space is assumed to be needed per employee or household in each land use class. We used the following space requirement rules for employment: industrial, 500 feet $^{2}\left(46.5 \mathrm{~m}^{2}\right)$ per employee, and a floor area ratio of 0.23 ; commercial high, 200 feet $^{2}\left(18.6 \mathrm{~m}^{2}\right)$ per employee and a floor area ratio of 0.35 ; commercial low, 300 feet $^{2}\left(27.9 \mathrm{~m}^{2}\right)$ per employee and a floor area ratio of 0.15 . The residential densities (inclusive of local streets) used were: residential high 2,150 feet $^{2}$ or 0.05 acre $\left(200 \mathrm{~m}^{2}\right)$; residential medium 0.2 acre $\left(800 \mathrm{~m}^{2}\right)$; residential low 5 acres $\left(20,200 \mathrm{~m}^{2}\right)$; and residential very low 20 acres $\left(80,900 \mathrm{~m}^{2}\right)$. These density figures were determined through a review of common residential and employment densities used in area general plans and were reviewed by the project steering committee.

Second, each of the eight counties' land use plans was used to identify where each land use type is permitted to develop. We used the eight counties' General Plans (Gao \& Johnston, 2004; State of California, 2008b) as the basis for the Status Quo base case because in California, land use decisions must, by law, be consistent with these formally adopted land use plans. Third, a set of prohibitions restricted where growth can go. The prohibitions used were: existing developed areas (Division of Land Resource Protection, 2004a), lakes (United States Geological Survey, 2004a), rivers (United States Geological Survey, 2004b), and publicly owned lands (California Resources Agency, 2005).

Finally, a set of factors representing features that attract or discourage urban growth was identified. These factors are used by UPlan to prioritize the sequential consumption of land with the highest net attraction values. Attractions and discouragements can take many forms. Accessibility is commonly considered to be growth-attracting (Iacono, Levinson, \& El-Geneidy, 2008) and is represented by ranking road networks according to the degree of access they provide. We used six attractors: census blocks with growth between 1990 and 2000 (GeoLytics 2001, 2006), freeway interchanges, other highways, major arterial roads, minor arterial roads, and city Spheres of Influence (representing areas with likely future water, sewer, roads, fire, police, and ambulance services). Similarly we used four discouragement factors: 100 year floodplains (Federal Emergency Management Agency, 1996), vernal pools (Holland, 1998), state 
records for threatened or endangered species (California Department of Fish and Game, 2006), and conservation priority areas (The Nature Conservancy, 2001), which reduced the suitability of these features for development. Each of these discouragements is representative of features that would add significant economic or legal costs to new development in these areas.

Each of the seven policy scenarios defined by the LUHA group was modeled using this method for a projected 2050 population of eight million people in eight counties and 62 cities (California Department of Finance, 2004). We evaluated two measures of interest to elected officials in this region: (1) loss of existing agricultural revenues based on current crop values; and (2) distance of new employment and residential locations from existing urban services as calculated by computing the number of residential and employment locations in each cell and computing a distribution of the number of units by distance from existing urban development.

\section{Scenario Definitions}

The seven scenarios defined and provided by the working group represent broad land use policy goals for the purpose of a first-stage regional alternatives assessment. These scenarios are representations of how the general plans of the eight counties and 62 cities might be amended to regionally reflect alternative urban growth policies. This type of scenario planning has worked successfully in the Sacramento region, just north of the SJV (Sacramento Area Council of Governments, 2007) and has been used in many other regions (Bartholomew, 2007). Scenario definitions are as follows:

Scenario 1 (S1). The Status Quo scenario is intended to represent current regional development trends. Its primary goals were to simulate what an extension of current patterns into the future might look like if we assume no major infrastructure investments or policy shifts. Largely unrestricted growth was permitted adjacent to existing developed areas and along transportation routes with relatively low residential densities, which emulates the region's recent past, determined by census block population data for 1990 and 2000 .
Scenario 2 (S2). The East-West Infrastructure Improvement scenario modeled potential investment to enhance transportation capacity along major east-west roads to resolve a common complaint about the roadway network in the SJV. This scenario permits expanded residential and commercial construction along these east-west highways, but assumes no other substantive changes from the Status Quo scenario.

Scenario 3 (S3). In the Compact Growth scenario, growth was restricted to the existing Spheres of Influence for each city, areas into which cities commit to providing services in 10-15 years (State of California, 2008a). This scenario reflects a class of controlled-growth policies where an urban growth boundary is set and new residential and employment space is restricted to within the boundaries. The lowest two of the four urban density classes in UPlan were collapsed into the more dense classes. If this change did not accommodate all of the residential demand within the Spheres of Influence, then density of the Residential Medium Class was increased. This is the only scenario that fully suppresses the lower two residential density categories. The assumed square footage of in-building employment space remained constant with the other scenarios. The floor area ratio was adjusted for the low-density commercial category to increase the efficiency of space use, thereby increasing employment density.

Scenario 4 (S4). This was originally called the Farmland Protection scenario by the LUHA Committee, but to be more descriptive it will be called the High-Value Soils Protection Scenario. It simulates protection of the most valuable agricultural lands through protection of the prime soils and farmlands classified as of statewide importance (Division of Land Resource Protection 2004a, 2004b). In this scenario no new development was permitted on these lands.

Scenario 5 (S5), the Exclusion Zone scenario, tries to protect agricultural lands between Interstate 5 and Highway 99, except in areas immediately adjacent to existing cities. The region between Highway 99 and Interstate 5 contains a large proportion of the prime and statewide-importance farmlands, as well as large contiguous blocks of other agricultural lands. Both this and Scenario 4 
are simplified representations of growth patterns advocated by some farm groups.

Scenario 6 (S6). The New Cities scenario removes the residential very-low density class and adopts a 15 percent density increase for all the remaining housing density classes. This reflects a vision of four new, large, self-sufficient cities at locations that serve to minimize the impact on important agricultural lands and habitats. These cities were sized to accommodate approximately 250,000 people each, which would be enough to provide a fully self-sustaining city with entertainment and commercial opportunities for the residents. This scenario emulates policies in which moderate housing density increases are combined with relocating growth to areas with reduced agricultural and species impacts, and which could be used by long-distance commuters from the Bay Area and Los Angeles.

Scenario 7 (S7). The Great Cities scenario concentrates growth into existing major urban areas and aggregates them into cluster sizes of greater than one million inhabitants. This scenario also eliminates the residential very-low density category and includes a 15 percent density increase across the remaining residential categories. The assumed benefits of this policy are that total impacts to agricultural land can be reduced through reduction of farmland fragmentation, that transit use can be increased through the creation of metropolitan areas suitable for extensive mass transit, and that the resulting cities would be large enough and support enough urban amenities to attract additional high-value business activity and employment.

\section{Agricultural Revenue Loss Calculations}

Our assessment of urban growth impacts on crop production is meant to be a snapshot of short-term losses due to projected urban patterns. We overlaid UPlan model outputs on crop-specific maps of the region and determined the acreage of each crop type lost to urbanization. The California Department of Water Resources (DWR) Land Cover map (California Department of Water Resources, 2006), which identifies crop type (Figure 1), was assembled for the eight-county region and served as the reference for calculating the amount of each crop type converted under each scenario. Crop values by type per acre were calculated based on 2004 crop values published in the 2004 or 2005 County Agriculture Commissioner's report for each county (Davis, 2006; Gudgel, 2006; Hudson, 2006; Kunkel, 2006; Niswander, 2006; Prieto, 2006; Robinson, 2006; Rolan, 2006). Each crop that was clearly identifiable in both the DWR data and the commissioner's reports was recorded for each county in a database table with its calculated value per acre. We only analyzed crops that were clearly identifiable and for which a value could be referenced, including 41 crops with revenue for at least one county and five with revenue in all counties (table 1).

We intersected county-level UPlan growth projections for each scenario with the DWR data and summarized the acres of each existing crop lost. The crop value lost in each county was calculated by multiplying the acres of each crop by the value per acre and aggregating to the regional level. This provides cross-comparable annual agricultural revenue lost per scenario. This calculation gives only the initial loss of revenues before the agricultural market re-equilibrates. A proper mediumterm evaluation would be difficult to perform, as almost all crops and even some grazing rely on irrigation, and water rights are very complex and uneven in the SJV. Also, many crops are expensive to relocate (orchards, vineyards). Our projections could be viewed as upper bounds, as some of these revenue losses would be compensated for with intensified cultivation on other lands or the substitution of previously unfarmed land. On the other hand, nearly all high-value arable lands in the region are under cultivation and all irrigation water is claimed, so there is not likely to be much new irrigated land put into production. Furthermore, large parts of the SJV are shifting to higher-value crops as global markets make commodities grown on high-value land with expensive water less competitive, so it is plausible that the long-term cost of lost productivity in high-sprawl scenarios could be even higher than calculated here. The substitution of alternative crops is, therefore, probably the greater concern, though many of the SJV's crops are already fairly high value crops including fruits, nuts, grapes and other specialty crops. This analysis is therefore broadly useful for ranking agricultural 


\section{Figure 1. Simplified Map of Crop Locations Near Fresno, California}

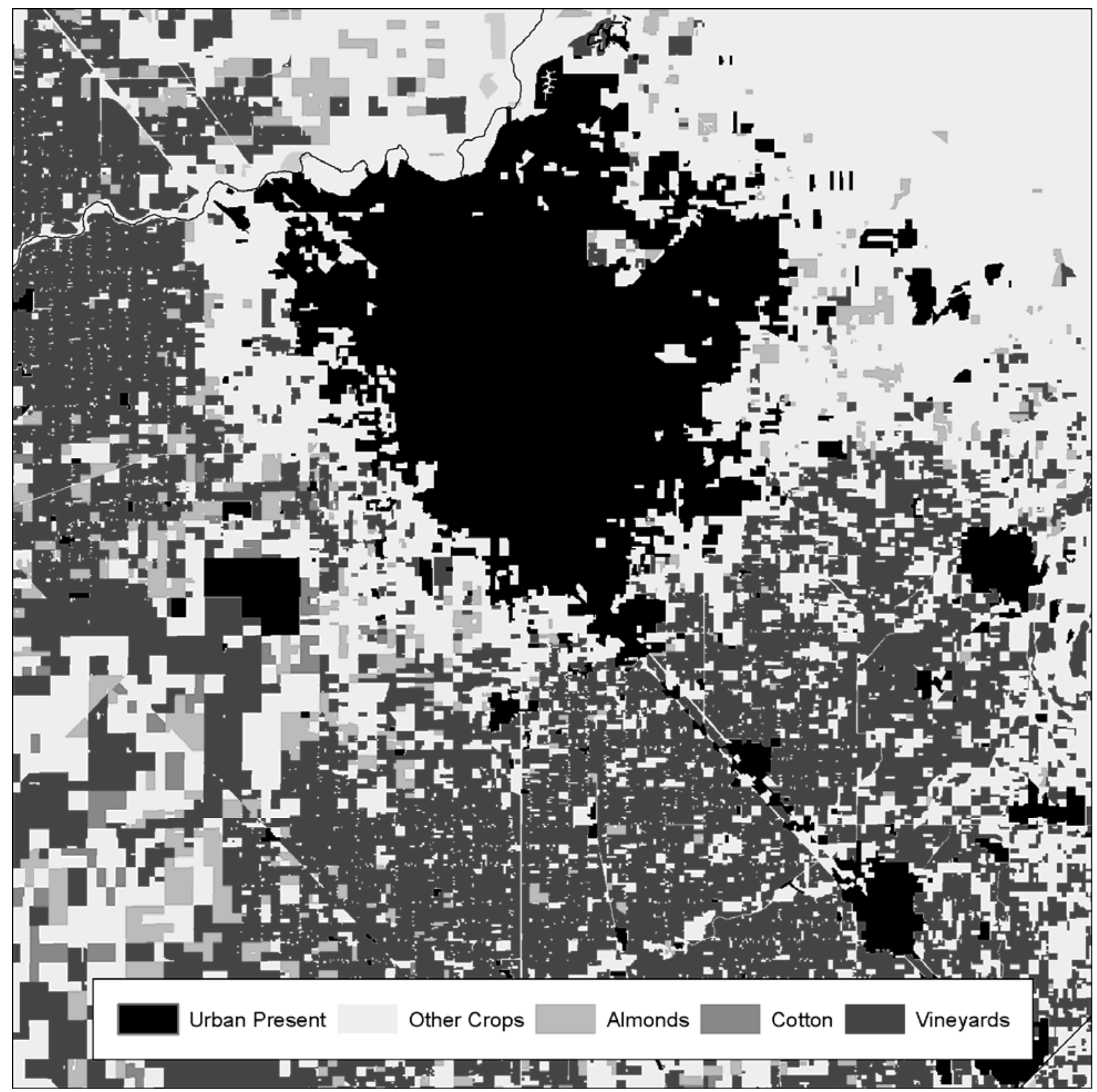

revenue loss but should not be taken as the best dollar estimate of future losses in any given scenario.

\section{Relative Service Cost Calculations}

Computation of costs for urban services and transportation required the development of a crosscomparable, nonmonetary metric as we could not find regionally suitable data on actual service provi- sion costs by distance from existing services or by housing density. Several articles and a ULI report in the mid-late 1980s (Frank, 1988, 1989; Frank, Downing, \& Lines, 1985; Frank \& Falconer, 1990) have been used to identify costs for providing services by distance from urban areas. However, we did not find any evidence of these methods' recent use. We quantified bulk mass distance, the number of new dwelling units, and employee 
Journal of Agriculture, Food Systems, and Community Development

ISSN: 2152-0801 online

www.AgDevJournal.com

Table 1. Calculated Cost to Each Crop (in USD) for the San Joaquin Valley by Each Scenario

Only crops that are have areas in the DWR Land Cover, have crop values in the agriculture commissioner's reports, and are impacted by at least one growth scenario are included.

\begin{tabular}{|c|c|c|c|c|c|c|c|}
\hline Land Cover & $\begin{array}{l}\text { Status Quo } \\
\text { (S1) }\end{array}$ & $\begin{array}{l}\text { East-West } \\
\text { Improvement } \\
\text { (S2) }\end{array}$ & $\begin{array}{l}\text { Compact } \\
\text { Growth } \\
\text { (S3) }\end{array}$ & $\begin{array}{l}\text { High-Value } \\
\text { Soils } \\
\text { Protection } \\
\text { (S4) } \\
\end{array}$ & $\begin{array}{l}\text { Exclusion } \\
\text { Zone } \\
\text { (S5) }\end{array}$ & $\begin{array}{c}\text { New Cities } \\
\text { (S6) }\end{array}$ & $\begin{array}{c}\text { Great Cities } \\
\text { (S7) }\end{array}$ \\
\hline Alfalfa & $60,940,910$ & $61,833,051$ & $9,687,227$ & $26,051,794$ & $23,620,683$ & $36,756,104$ & $47,287,947$ \\
\hline Almonds & $364,654,877$ & $369,644,236$ & $50,858,551$ & $122,715,242$ & $353,598,518$ & $231,939,029$ & $267,028,587$ \\
\hline Apples & $9,457,529$ & $10,613,294$ & $4,347,176$ & $4,052,124$ & $10,474,021$ & $10,647,063$ & $10,529,289$ \\
\hline Apricots & $4,026,308$ & $3,859,447$ & 303,065 & $1,030,589$ & $1,455,438$ & $4,128,148$ & 99,219 \\
\hline Asparagus & $1,304,579$ & $1,304,579$ & & & 397,082 & & \\
\hline Barley & 97,807 & 108,355 & 33,762 & 97,974 & 85,702 & 66,174 & \\
\hline Beans & $12,296,255$ & $12,194,184$ & $1,966,719$ & $1,630,280$ & $3,125,867$ & $8,189,223$ & $7,399,858$ \\
\hline Broccoli & 568,607 & 567,272 & & 9,152 & 179,969 & 7,095 & 186,064 \\
\hline Cauliflower & 422,506 & 475,891 & & 76,720 & 155,583 & 162,129 & 197,850 \\
\hline Cherries & $4,080,278$ & $4,098,850$ & 194,612 & 622,438 & $4,210,040$ & $2,874,091$ & $2,468,259$ \\
\hline Corn & $148,006,167$ & $144,921,109$ & $16,930,585$ & $97,781,550$ & $72,943,904$ & $106,145,663$ & $80,138,166$ \\
\hline Cotton & $103,550,044$ & $102,854,426$ & $16,850,819$ & $33,037,535$ & $39,984,158$ & $58,405,429$ & $48,336,821$ \\
\hline Figs & $3,706,481$ & $3,372,310$ & 114,369 & $3,332,019$ & $4,907,762$ & $2,492,846$ & \\
\hline Grain and hay & $9,669,465$ & $9,698,818$ & $1,700,170$ & $9,505,188$ & $8,102,780$ & $5,778,740$ & $7,513,034$ \\
\hline Grain sorghum & 65,150 & 65,150 & 3,593 & 461 & 89,187 & 4,511 & 10,381 \\
\hline Grapefruit & $2,432,553$ & $2,413,928$ & 111,167 & 712,202 & $3,273,835$ & $1,836,860$ & 183,200 \\
\hline Kiwis & $3,516,769$ & $3,444,320$ & 464,075 & 805,430 & $5,549,634$ & $1,960,481$ & $1,867,445$ \\
\hline Lemons & $13,489,316$ & $13,077,523$ & $2,691,303$ & $10,791,154$ & $16,281,414$ & $8,628,955$ & $6,394,487$ \\
\hline Lettuce & $1,340,863$ & $1,340,863$ & 19,980 & 519,477 & 512,099 & 703,301 & $1,271,812$ \\
\hline Melons squash & $13,993,654$ & $13,690,242$ & $1,044,930$ & 683,545 & $3,295,699$ & $5,550,525$ & $3,307,064$ \\
\hline Olives & $11,174,561$ & $11,114,244$ & $1,633,455$ & $1,656,985$ & $15,093,202$ & $7,996,685$ & $2,691,301$ \\
\hline Onions garlic & $23,684,217$ & $23,758,163$ & $1,191,886$ & $5,631,546$ & $10,290,056$ & $27,175,123$ & $4,193,468$ \\
\hline Oranges & $192,532,448$ & $192,127,695$ & $25,925,023$ & $65,217,323$ & $291,184,411$ & $127,378,583$ & $92,417,251$ \\
\hline Peaches & $156,451,035$ & $155,920,496$ & $29,744,419$ & $29,116,918$ & $228,351,488$ & $116,347,471$ & $93,492,349$ \\
\hline Pears & $1,890,723$ & $1,890,723$ & 12,082 & 722,497 & $2,596,583$ & $1,149,971$ & 446,873 \\
\hline Peppers & $2,954,283$ & $2,233,779$ & 12,424 & $4,801,058$ & $2,777,016$ & $7,924,019$ & $2,251,379$ \\
\hline Pistachios & $35,890,046$ & $37,869,159$ & $6,032,141$ & $14,806,346$ & $52,528,788$ & $15,770,363$ & $14,455,491$ \\
\hline Plums & $58,557,813$ & $58,345,354$ & $10,942,686$ & $12,596,513$ & $80,040,230$ & $39,429,520$ & $46,172,968$ \\
\hline Potatoes & $9,188,743$ & $10,344,744$ & $1,354,640$ & $13,620,821$ & $13,774,150$ & $9,405,584$ & $16,783,752$ \\
\hline Prunes & $1,585,574$ & $1,568,157$ & & 133,605 & $1,486,135$ & 490,795 & 107,236 \\
\hline Rice & $1,227,611$ & $1,175,925$ & 106,794 & $1,105,326$ & 710,555 & 432,202 & 303,298 \\
\hline Safflower & 131,636 & 146,520 & & 217,115 & 149,779 & 5,870 & 7,426 \\
\hline Spinach & 93,863 & 93,863 & & & & 93,863 & \\
\hline Strawberries & $2,678,941$ & $2,673,267$ & $1,580,786$ & 235,639 & $2,805,057$ & $2,449,813$ & $1,713,610$ \\
\hline Sudan & 674,176 & 644,916 & 84,235 & 283,039 & 376,130 & 400,326 & 254,401 \\
\hline Sugar beets & $4,882,703$ & $4,925,517$ & 572,783 & $1,351,918$ & $1,989,144$ & $2,284,002$ & $2,615,615$ \\
\hline Sweet potatoes & $15,100,588$ & $13,908,545$ & $3,498,327$ & $3,712,383$ & $8,683,780$ & $9,050,045$ & $1,221,192$ \\
\hline Tomatoes & $67,971,722$ & $67,394,561$ & $3,526,071$ & $8,396,243$ & $13,053,063$ & $51,391,088$ & $39,167,294$ \\
\hline Vineyards & $361,460,442$ & $358,454,119$ & $52,015,195$ & $139,042,208$ & $387,727,065$ & $225,857,301$ & $332,696,871$ \\
\hline Walnuts & $49,629,209$ & $51,477,450$ & $12,071,922$ & $7,898,565$ & $47,932,055$ & $37,894,963$ & $76,360,753$ \\
\hline Total & $1,755,380,452$ & $1,755,645,043$ & $257,626,974$ & $624,000,921$ & $1,713,792,062$ & $1,169,203,951$ & $1,211,572,015$ \\
\hline
\end{tabular}

locations within a set of distance bands from existing urban services as a useful representation of expected relative costs for new urban service provision. We present this as a histogram, with the notable features being the number of new units in each distance class. We assume this measure will correlate with service costs (i.e., operation and maintenance costs should scale approximately to the distances covered). This method is therefore suitable for ranking the broad policy scenarios for 
the SJV and is appropriate because it will scale with inflation or other factors that may cause the costs to vary over time.

\section{Results}

\section{Agricultural Annual Revenue Loss Calculations}

The area of crops lost and total annual value of crops lost varied dramatically between scenarios (table 2). The Status Quo (S1), East West Infrastructure (S2), and Exclusion Zone (S5) scenarios had the highest costs at over USD1.7 billion in crop value lost. The New Cities (S6) and Great Cities (S7) scenarios formed a second cost class at approximately USD1.2 billion. The High-Value Soils Protection (S4) scenario produced costs of approximately USD600 million and, finally, the Compact Growth (S3) scenario created a cost of approximately USD250 million.

The footprint of each scenario (figure 2) impacted specific crops in different ways (see table 1 again). The Exclusion Zone scenario (S5) forced growth into the foothills around the valley, which increased the revenue lost for the peach, orange, pistachio, and plum crops, while scenarios S1, S2, and $\mathrm{S} 7 \mathrm{had}$ a distinct impact on many of the highvalue, high-employment crops (e.g., vine and tree crops) grown immediately adjacent to existing cities

Table 2. Acres (Hectares) Included in Value Calculations and Associated Annual Loss of Revenues (2004 USD)

\begin{tabular}{lcc}
\hline & Acres (Hectares) & Annual Loss in Crop Value \\
\hline Total & $4,925,660(1,993,342)$ & $10,827,056,000$ \\
\hline $\begin{array}{l}\text { Status Quo } \\
\text { (S1) }\end{array}$ & $679,876(275,136)$ & $1,755,380,452$ \\
\hline $\begin{array}{l}\text { East-West Improvement } \\
\text { (S2) }\end{array}$ & $679,980(275,178)$ & $1,755,645,043$ \\
\hline $\begin{array}{l}\text { Compact Growth } \\
\text { (S3) }\end{array}$ & $114,857(46,481)$ & $257,626,974$ \\
$\begin{array}{l}\text { High-Value Soils Protection } \\
\text { (S4) }\end{array}$ & $266,155(107,709)$ & $624,000,921$ \\
\hline $\begin{array}{l}\text { Exclusion Zone } \\
\text { (S5) }\end{array}$ & $550,222(222,667)$ & $1,713,792,062$ \\
\hline $\begin{array}{l}\text { New Cities } \\
\text { (S6) }\end{array}$ & $444,278(179,793)$ & $1,169,203,951$ \\
\hline $\begin{array}{l}\text { Great Cities } \\
\text { (S7) }\end{array}$ & $550,721(222,869)$ & $1,211,572,015$ \\
\hline
\end{tabular}

on prime agricultural lands.

The Status Quo (S1), East-West Infrastructure Improvements (S2), and Exclusion Zone (S5) scenarios all had relatively similar impacts on loss of agricultural production. The spatial congruence of the Exclusion Zone scenario (S5), however, differed greatly from the other two. It had a similar agricultural cost (USD1.7 billion), but the crops impacted were different. S1 and S2 impact more field crop and vegetable types (corn, cotton, grains, and tomatoes), while S5 heavily impacts fruits in the lower foothills (olives, pistachios, citrus, stone fruits, and, to a smaller extent, vineyards) (table 1). We also found that the High-Value Soils Protection (S4) scenario, which prohibited new growth on soils classified as Prime or of Statewide Importance for agriculture, had less value lost (USD620 million) than S1, S2, or S5, and achieved significant savings across almost all crop types. But, because of its focus on preserving particular soil classes and its lower density of development, the High-Value Soils Protection scenario was not as effective in protecting the agricultural economy as the Compact Growth (S3) scenario.

The crop value losses for the New Cities (S6) and Great Cities (S7) scenarios converged at approximately two thirds (approximately USD1.2 billion) of the cost of the Status Quo (S1) scenario.

Again, they reached similar values but impacted crops differently. S6 reduced impacts to almond and vineyard production compared with S7, but increased losses in the orange and tomato crops. The sizeable shift in costs to orange production is largely the result of the encouragement of concentrated growth around urban centers in $\mathrm{S} 7$ that does not exist as strongly in S6. That same attraction around existing urban areas is responsible in $\mathrm{S} 7$ for the larger losses to vineyard and almond production. It is 
Figure 2. Urban Growth Scenarios in the Central Four Counties of the San Joaquin Valley (Scenario 2 was omitted because of its similarity to Scenario 1 at this scale.)

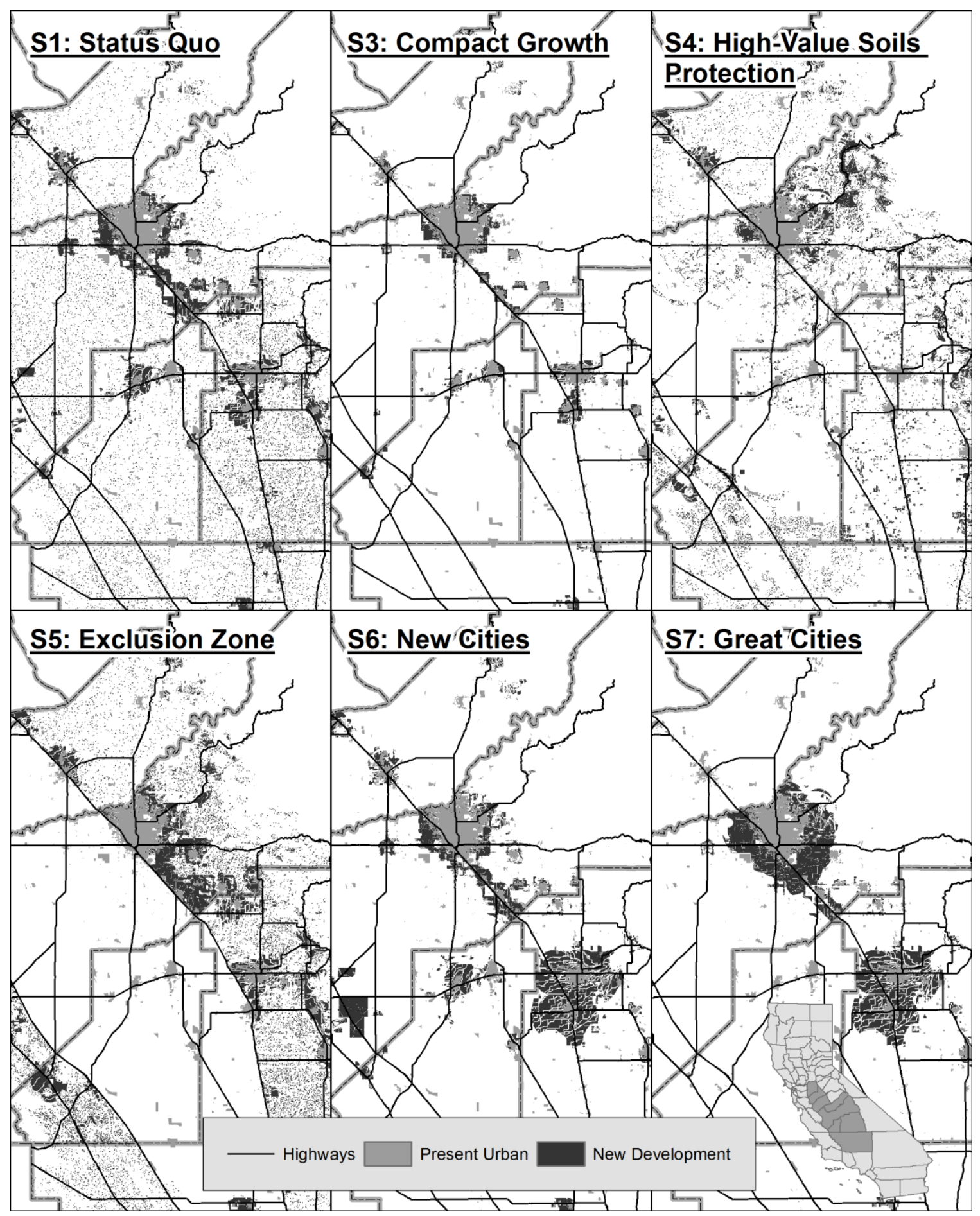


important to note that neither S6 nor S7 had the same density advantage given to Compact Growth (S3), and that, as a result, a direct comparison of the differences between the scenarios is difficult. The S3 scenario had by far the smallest consumption of land and consequently the smallest impact on current agricultural production. The net loss to agriculture in S3 (USD258 million) is under one sixth of that under current policy (S1). Every crop was significantly less impacted under S3 than S1, and only the S4 scenario showed any crops retaining more revenue than in $\mathrm{S} 3$.

\section{Relative Urban Service Cost Calculations}

The level of urban development at varying distances from existing urban areas differed considerably (figure 2). The more dispersed development patterns of New Cities (S6) and High-Value Soils Protection (S4) result in new development at noticeably longer distances from exiting urban spaces (figure 3) and with a lower percentage of their development in the first few distance bands, implying that these scenarios would be the most costly in terms of government and private services required. Status Quo (S1), East-West Highway Infrastructure Improvement (S2), Exclusion Zone (S5), and New Cities (S7) scenarios all had similar spatial patterns as well as similar development profiles by distance from existing urban areas (bulk mass distance).

The Compact Growth (S3) scenario had the shortest new development distant from urban services. The maximum residential density of just over eight dwelling units per acre used to achieve

Figure 3. Percent of New Development by Distance from Existing Urban Space

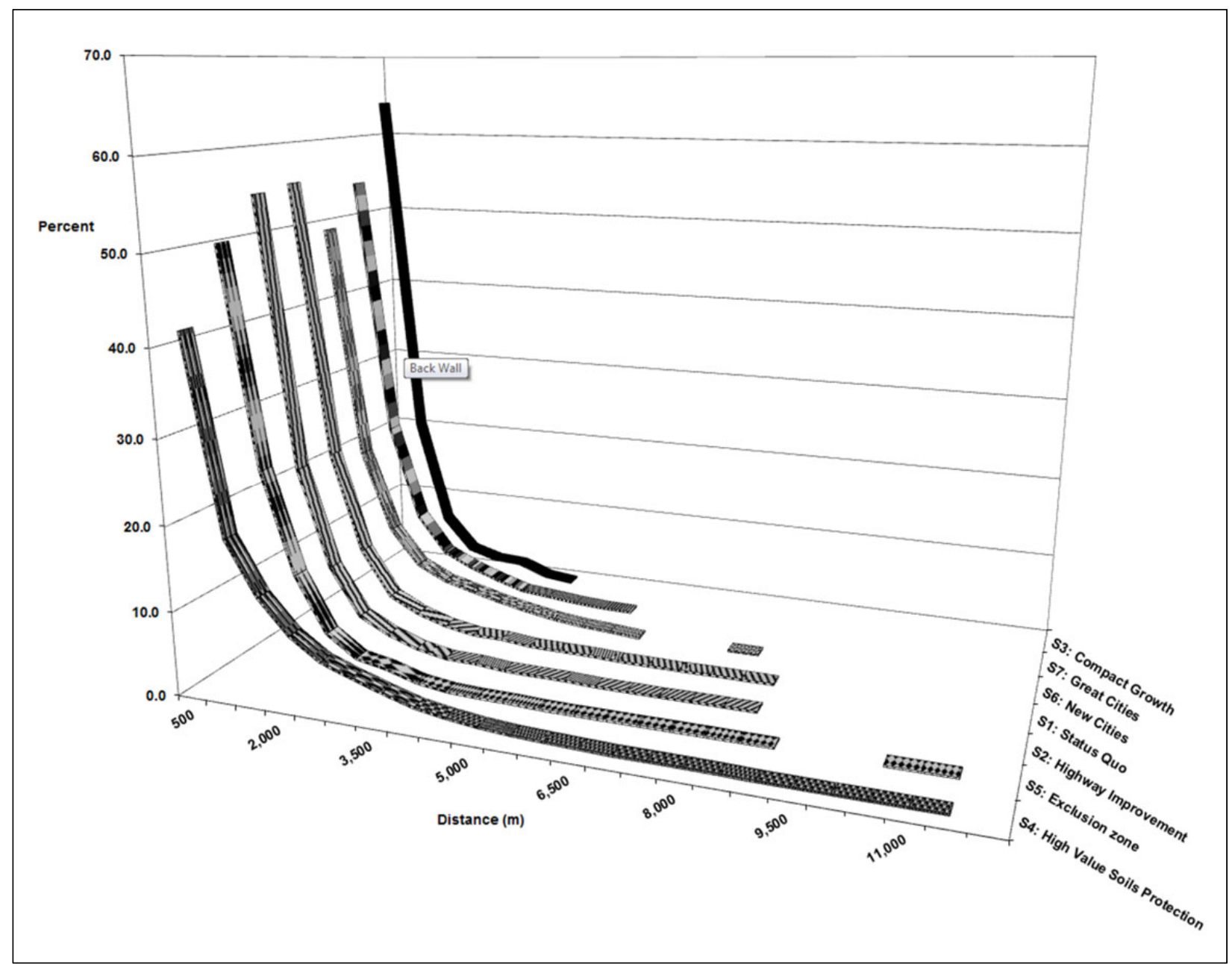


the build-out in this scenario is not any higher than is found in many coastal California cities. The S3 bulk mass distance was much smaller than Status Quo's (S1) because the population growth was concentrated closely around existing urban areas, requiring an expansion of services into a comparatively small area.

The New Cities (S6) scenario increased bulk mass distance over Status Quo (S1) (figure 3). The maximum distance of growth away from existing urban areas remained similar to S1, but the number of housing units and employment locations immediately adjacent to existing urban areas decreased. The creation of an entirely new city in a location with limited existing services will require the development of new infrastructure. The mass of new residences in a location remote from existing urban development is identifiable in the bulk mass distance measure of $\mathrm{S} 6$.

The Status Quo (S1), East-West Infrastructure Improvement (S2), and Great Cities (S7) scenarios, had very similar impacts on the bulk mass distance for urban services. The Exclusion Zone (S5) scenario produced larger bulk mass distances than $\mathrm{S} 1$ and resulted in new development beyond our cut-off distance of 7.8 miles $(12.5 \mathrm{~km})$ from existing urban areas (figure 3). However, High-Value Soils Protection (S4) produced by far the most expansive and widely dispersed urban growth pattern. The High-Value Soils Protection scenario, with protected farmland defined only by the narrow metric of soil class, would require extensive investment in providing urban services to a very dispersed set of small population centers.

\section{Discussion}

The identification of different urban growth and transportation policies by the SJV regional planning consortium provided the basis for exploring the possible consequences of those policies on urban service provision and agricultural revenue. Each scenario had distinct policy criteria reflecting the preferences of particular interest groups and produced a unique urban footprint. UPlan proved useful as a GIS-based modeling tool to visualize and quantify the impacts.

The Compact Growth scenario had the lowest cost in terms of both agricultural production losses and urban services provision. The more compact growth pattern also reduces the need to travel long distances and would increase the utility of public transit (Ewing \& Cervero, 2001). It is also worth noting that a compact growth pattern reduced the length of the border between developed and agricultural lands. The reduction in the agricultureurban interface creates a smaller potential zone of conflict over land uses and limits the negative effects of the urban area on agricultural productivity (Sokolow, Hammond, Norton, \& Schmidt, 2010). Additionally, the more dispersed patterns visible in S1, S2, S4, and S5 are likely to place more traffic onto rural roads, increasing the potential conflict between agricultural and other vehicle traffic.

Both the High-Value Soils Protection and Exclusion Zone scenarios are attempts to protect farmland from development through blanket prohibitions. These policies produced very dispersed urban growth patterns that would require relatively high expenditures for services. These effects are the products of an oversimplified policy objective, the preservation of specific soil types, but one which is representative of the type of mitigation proposals often made to advance farmland and other terrestrial conservation goals. The S3, S4, and S5 scenarios suggest that a policy of trading off development of prime agricultural land immediately adjacent to urban areas in exchange for the achievement of significantly higher urban densities could prove valuable in this region.

Perhaps surprisingly, the evaluation of crop losses showed that the High-Value Soils protection scenario, a theme of common interest to many farm groups, was not as effective in protecting the agricultural economy as the Compact Growth (S3) scenario, a strategy typically endorsed by urbanfocused interests. The New Cities (S6) scenario has great potential for locating new growth away from areas with high resource values, whether agricultural or natural. This scenario could also reduce the need for residents to travel to other cities. While S6 did not include the increased urban density used by S3 to accommodate the new population growth, the S6 policy scenario would undoubtedly benefit from similar higher densities in terms of infrastructure costs and impacts on the agricultural 
economy. These densities might be more easily achievable because the new cities could be free of conflicts with existing residents. We did not attempt to quantify what the cost of building new cities might be. Similarly, the Great Cities (S7) scenario has the potential to reduce the impacts of development on agriculture and urban service provision while providing the region with amenities now only found in California's large coastal cities. Both scenarios 6 and 7 have similar advantages to S3, stemming from less farmland fragmentation and reduced space for conflict along the urbanrural interface. Applying the compact growth principles of S3 to both S6 and S7 could result in further benefits to the agricultural economy. The Status Quo (S1) and the similar East-West Highway Infrastructure Improvement (S2) scenarios produced roughly the same results and were costly compared to the other scenarios. The Status Quo is not the best scenario on which to pattern future land use policies, based on the measures reported here. All the other scenarios performed better by either retaining higher agricultural production or producing lower urban services costs.

Interestingly, the relationship of a scenario's agricultural impact and its impact on important habitat types and on habitat connectivity is a complex issue. The same urban growth scenarios were analyzed by Beardsley et al. (2009) and Huber et al. (2011). Their results show clearly that habitat conservation or habitat connectivity protection and farmland revenue protection, while frequently convergent, are not always mutually supportive, particularly in cases where the habitat values are subject to being severed by urban growth along riparian corridors or relocation of urban growth to sensitive areas.

It is also important to note that agricultural land can produce a number of ecosystem services over and above the value associated with the crop production or habitat value. These may include flood mitigation, carbon sequestration, open space existence value, pollination services, and improvements in ground water quality (Allen \& Vandever, 2003). The true values of these ecosystem services to a region are difficult to calculate, as these are generally considered public goods and their value is rarely fully capitalized in land values, but can be estimated through bottom-up econometric analyses (Sandhu, Wratten, Cullen, \& Case, 2008) and survey methods such as contingent valuation (Randall, 2007). We also note that the benefits accrued from ecosystem services are dependent on the management regime.

The Governor's Partnership for the San Joaquin Valley recommended in its Strategic Action Proposal (California Partnership for the San Joaquin Valley, 2006) that future growth would require careful and coordinated regional planning to protect the SJV's environment for health, agricultural, and environmental purposes. UPlan proved to be a valuable visioning tool for this effort. It permitted a large group of local agencies to develop and modify scenarios rapidly enough to fulfill state planning mandates within a limited time. The model outputs were useful for ranking the scenarios by various criteria. The ability of the GIS models to permit comparison of impacts on agricultural lands, service costs, and other factors permitted a broad set of constituents to use the results in planning.

As in most GIS analyses, availability of data is a limiting factor. In a process such as this one, specific crop location data and revenue data both must be available, preferably for a very closely matched time frame, in order to accurately calculate agricultural costs and benefits. Overall, the GIS processes are straightforward; the greater challenge was in managing the output data and summarizing it using database tools. However, the GIS-based approach permitted an assessment of some of the costs associated with varying urban growth policies, something that, to our knowledge, has not been attempted in similar studies.

For others who may wish to replicate this analysis in other agricultural regions, several components are needed. First, some hypotheses about the patterns of future urban growth are needed in order to develop the parameters for UPlan. Second, the extent, variety, and location of crops are needed, preferably specific to each field and with suitable spatial accuracy to represent the loss of individual fields. One must also gather crop value data that matches the time frame of the crop locations. In this respect our process could be improved because we had crop location data from 
a range of years and crop revenue data from a single year. The crop revenue may be available from various types of government accounting offices, either as summaries of the value produced per crop per region or from tax records. The location and availability of these data are likely to be specific for each region considered, depending on the local governing structures. California, in particular, may have better data available due to crop reporting requirements. Barring those data acquisition steps, any footprint of land use conversion can be used in a GIS process as described here to calculate the revenue lost through conversion of agricultural land to other purposes by replicating the general steps of calculating the area of each crop converted in GIS and multiplying it by a revenue value per acre. We included a little additional complexity by addressing a multicounty region and allowing agricultural revenue for each crop to vary between counties. Further improvements to this method could be made with improved datasets, such as having field-specific revenue values for each crop.

Another consideration is the ease with which different crops can be relocated, either by displacing other, presumably lower-value crops or through the conversion of natural lands into agriculture. We did not attempt this projection because of the complexity involved in forecasting crop movements by multiple farmers under challenging agricultural conditions.

Calculation of service costs is the third component of this modeling exercise. Services are provisions by local government, in this case by incorporated cities and towns. We made the assumption that further distances from existing infrastructure would be relatively more expensive. While this seems a fairly safe assumption, there may be more information available for other studies as to the costs of particular services that would permit actual rather than relative value projections.

As noted elsewhere in this text, there are limitations to the methods demonstrated here. This analysis includes only the lost agricultural revenue from land conversion and does not address potential long-term benefits to farmers or communities from the sale and conversion of land to other uses. However, we feel that quantification of the loss of agricultural land, crop production, and agricultural revenue is useful in its own right. The loss of farmgate revenue relates implicitly to the loss of farm jobs, though quantifying the job loss or number of agribusinesses that may be impacted would require more baseline data than was readily available. Such results illustrate the potential impacts to regional agricultural production, exports, food security, and local government costs that can be important for land use decision-making. These analyses may be particularly important for regions with both an economically important agricultural sector and rapid urban expansion.

This analysis is not intended to be all-encompassing. Neither funding nor impending deadlines for policy applications by SJV planners permitted us to extend the analysis to cover the larger range of potential effects. Rather than considering it a full analysis of all effects created through a change in land use policy, we present a technique to describe the scenarios' effects along two individual dimensions, sometimes called performance measures. These policies represented by the scenarios may have other effects that compensate for or detract from quality of life that we do not address. For example, depending on the agricultural practices, conversion of agricultural land to urban uses may decrease costs related to water and air quality, thereby reducing the net effect of protecting agricultural revenue. Similarly, the argument can be made that the land use policies represented will have effects on land values that could influence the net benefits realized by developers and land owners. Furthermore, these scenarios could have differential effects on the non-agricultural economy by affecting business and employee location choices and options for business practices. Given low average incomes and a large number of new people expected in the region, such spatial shifts in the location of jobs could potentially raise environmental justice issues. Additional analyses are possible, such as assessment of the environmental consequences of these scenarios, which were examined by Huber et al. (2011) and Beardsley et al. (2009) using different methods. Other techniques for evaluating location accessibility and travel behavior have been applied to similar scenarios (Niemeier et al., 2011). Obviously the 
range of potential impacts goes far beyond the set presented in this article. Many or all of these would require further study based on local data and accepted methods before a scenario should be selected for implementation.

Without going into detail, the broader conclusions drawn through this article that higher density and contiguous urban growth is more beneficial to agricultural revenue and to urban service provision reinforce the existing literature on the benefits of compact growth, namely, that compact growth produces shorter travel distances to necessary services, easier access to destinations, lower costs for system maintenance, and development and a reduced environmental footprint. Further, compact development with a range of housing and employment options promotes the availability of locally affordable housing to the full range of the socioeconomic spectrum.

The method presented in this paper can be completed using relatively straightforward GIS and easily accessible data to calculate the agricultural revenue impacts. An American Farmland Trust (AFT) report (1995) similarly analyzed two land use scenarios in the SJV defined by differences in density, with similar conclusions to those we found. The AFT report conducted a more in-depth economic analysis based on the comparison of the two scenarios whose primary difference was in urban density. In general our spatially explicit results appear similar, although the dollar values are indexed to years a decade apart. The total off-thefield revenue loss presented by the AFT is approximately 15 percent of the annual farmgate revenue for the region in the low-density scenario. The high-density scenario analyzed forecasts suggests a 7 percent loss in annual revenue, compared to 2 percent in our model, but assumes a density of six dwelling units per acre compared to the nine assumed in our compact scenario.

To the best of our knowledge there have been no other studies that have taken a farmland revenue-based approach to evaluating the value of farmland lost to urbanization at a regional scale. The modeling required to evaluate the long-term revenue lost following the reestablishment of equilibrium is both complex and subject to many possible confounding factors, and as such was beyond the scope of this simple toolset.

This round of modeling was an initial, regional planning phase that is to be followed by moredetailed GIS modeling by each county. In the second stage, the counties will run travel models in parallel with UPlan over time. This process will permit the examination of road congestion and investment costs. Land use priorities and plans will then be redrafted with the aid of better understanding of the likely consequences of land use decisions.

This study demonstrates the utility of quantitative comparisons of GIS-based model outputs for different development scenarios. Through this analysis, an environmentally benign option that also benefits the farm economy more than farm protection-specific policies was identified. The value of this exercise is that it laid the groundwork for a discussion of values and tradeoffs among competing ends. In November 2008, a Valley-wide advisory group (consisting of elected governing body members, appointed planning commissioners, planning directors, and major developers), voted to recommend a compact growth scenario based on a policy very similar to scenario 3 (Compact Growth) presented here.

\section{Acknowledgements}

The authors would like to thank the Great Places Program of the California Resources Agency, which provided support for the modeling and data collection efforts. Eric Lehmer and Dr. Shengyi Gao were also instrumental in the development of UPlan and the model runs used for subsequent analysis.

\section{References}

Abraham, J. E., \& Hunt, J. D. (2003). Market-based linkages in integrated land use transport models. Presented at the 8th International Conference on Computers in Urban Planning and Urban Management, Sendai, Japan. Retrieved from http://www.ucalgary.ca/ 〜jabraham/Papers/markets/summary.html

Ackerman, W. V. (1999). Growth control versus the growth machine in Redlands, California: Conflict in urban land use. Urban Geography, 20(2), 146-167. http://dx.doi.org/10.2747/0272-3638.20.2.146 
Allen, A.W., \& Vandever, M. W. (2003). A national survey of Conservation Reserve Program (CRP) participants on environmental effects, wildlife issues, and vegetation management on program lands. U.S. Geological Survey Biological Science Report. Washington, D.C.: U.S. Geological Survey.

Alterman, R. (1997). The challenge of farmland preservation: Lessons from a six-nation comparison. Journal of the American Planning Association, 63(2), 220-243. http://dx.doi.org/10.1080/01944369708975916

American Farmland Trust. (1995). Alternatives for future urban growth in California's Central Valley: The bottom line for agriculture and taxpayers (p. 25). Washington, D.C.: American Farmland Trust. Retrieved from http://www.farmlandinfo.org/documents/30361/ FUTURE URBAN GROWTH IN CALIFORN IAS CENTRAL VALLEY.pdf

American Farmland Trust. (2007, December 5). The future is now: Central Valley Farmland at the tipping point. Retrieved March 3, 2010, from http://www.farmland.org/programs/states/ futureisnow/default.asp

Bartholomew, K. (2007). Land use-transportation scenario planning: promise and reality. Transportation, 34(4), 397-412. http://dx.doi.org/10.1007/s11116-006-9108-2

Beardsley, K., Thorne, J. H., Roth, N., Gao, S., \& McCoy, M. C. (2009). Assessing the influences of rapid urban growth and regional policies on biological resources. Landscape and Urban Planning, 93(3-4), 172-183. http://dx.doi.org/10.1016/ j.landurbplan.2009.07.003

Bengston, D. N., Fletcher, J. O., \& Nelson, K. C. (2004). Public policies for managing urban growth and protecting open space: policy instruments and lessons learned in the United States. Landscape and Urban Planning, 69(2-3), 271-286. http://dx.doi.org/10.1016/j.landurbplan.2003. $\underline{08.007}$

Bengston, D. N., \& Youn, Y.-C. (2006). Urban containment policies and the protection of natural areas: The case of Seoul's greenbelt. Ecology and Society, 11(1), 15. http://www.ecologyandsociety. org/vol11/iss1/art3/

Brabec, E., \& Smith, C. (2002). Agricultural land fragmentation: The spatial effects of three land protection strategies in the eastern United States. Landscape and Urban Planning, 58(2-4), 255-268. http://dx.doi.org/10.1016/S0169-2046(01)00225-0

Bradshaw, T. K., \& Muller, B. (1998). Impacts of rapid urban growth on farmland conversion: Application of new regional land use policy models and geographical information systems. Rural Sociology, 63(1), 1-25. http://dx.doi.org/10.1111/j.15490831.1998.tb00662.x

Brueckner, J. K. (2000). Urban sprawl: Diagnosis and remedies. International Regional Science Review, 23(2), 160-171. http://dx.doi.org/10.1177/016001700761012710

Burchell, R. W. (2002). Costs of Sprawl-2000. Transit Cooperative Research Program. Washington, D.C.: National Academy Press.

Byrd, K. B., Rissman, A. R., \& Merenlender, A. M. (2009). Impacts of conservation easements for threat abatement and fire management in a rural oak woodland landscape. Landscape and Urban Planning, 92(2), 106-116. http://dx.doi.org/ 10.1016/j.landurbplan.2009.03.003

California Department of Finance. (2004). Population projections by race/ etbnicity, gender and age for California and its counties 2000-2050. Retrieved from http://www.dof.ca.gov/research/demographic/ reports/projections/interim/view.php

California Department of Fish and Game. (2006). California Natural Diversity Database. Sacramento, California: Author.

California Department of Water Resources. (2006). Land use survey. Sacramento, California. Retrieved from http://www.water.ca.gov/landwateruse/ lusrvymain.cfm

California Partnership for the San Joaquin Valley. (2006). Strategic Action proposal. Retrieved from http://www.sjvpartnership.org/uploaded files/ fck/Partnership SAP.pdf

California Resources Agency. (2005). Public and conservation trust lands. Sacramento, California: California Resources Agency.

Carruthers, J. I., \& Ulfarsson, G. F. (2003). Urban sprawl and the cost of public services. Environment and Planning B-Planning and Design, 30(4), 503-522. http://dx.doi.org/10.1068/b12847 
Clarke, K. C., \& Gaydos, L. J. (1998). Loose-coupling a cellular automaton model and GIS: Long-term urban growth prediction for San Francisco and Washington/Baltimore. International Journal of Geographical Information Science, 12(7), 699-714. http://dx.doi.org/10.1080/136588198241617

Davis, C., \& Schaub, T. (2005). A transboundary study of urban sprawl in the Pacific Coast region of North America: The benefits of multiple measurement methods. International Journal of Geographical Information Science, 7(4), 268-283.

Davis, T. K. (2006). 2004 Kern County Crop Report Retrieved from http://www.kernag.com/caap/ crop-reports/crop00_09/crop2004.pdf

Davis, T. S., Nelson, A. C., \& Dueker, K. T. (1994). The New Burbs: The Exurbs and Their Implications for Planning Policy. Journal of the American Planning Association, 60(1), 45-59. http://dx.doi.org/10.1080/01944369408975551

Dietzel, C., Herold, M., Hemphill, J. J., \& Clarke, K. C. (2005). Spatio-temporal dynamics in California's central valley: Empirical links to urban theory. International Journal of Geographical Information Science, 19(2), 175-195.

http://dx.doi.org/10.1080/13658810410001713407

Division of Land Resource Protection. (2004a). A guide

to the farmland mapping and monitoring program.

Sacramento, California: California Department of

Conservation. Retrieved from

http://www.conservation.ca.gov/dlrp/fmmp/

Documents/fmmp guide 2004.pdf

Division of Land Resource Protection. (2004b).

Farmland mapping and monitoring GIS data.

Sacramento, California: California Department of Conservation.

Ewing, R. (1997). Is Los Angeles-style sprawl desirable? Journal of the American Planning Association, 63(1), 107-126. http://dx.doi.org/10.1080/01944369708975728

Ewing, R., Pendall, R., \& Chen, D. (2003). Measuring sprawl and its transportation impacts. Transportation Research Record: Journal of the Transportation Research Board, 1831, 175-183. Retrieved from http://dx.doi.org/10.3141/1831-20

Ewing, R., Reid, \& Cervero, R. (2001). Travel and the built environment: A synthesis. Transportation
Research Record: Journal of the Transportation Research Board, 1780, 87-114. http://dx.doi.org/10.3141/1780-10

Fazal, S. (2001). The need for preserving farmland A case study from a predominantly agrarian economy (India). Landscape and Urban Planning, 55(1), 1-13. http://dx.doi.org/10.1016/S0169-2046(00)00134-1

Federal Emergency Management Agency. (1996). FEMAQ 3 Flood Data. Washington D.C.: Environmental Systems Research Incorporated (ESRI).

Frank, J. E. (1988). Legislative and judicial factors in the United States trend to finance community infrastructure by means of impact fees. Urban Law and Policy, 9(3), 219-230.

Frank, J. E. (1989). The costs of alternative development patterns. Washington, D.C.: Urban Land Institute.

Frank, J. E., Downing, P. B., \& Lines, E. R. (1985). A national survey of sewer impact fees. Journal of $W$ ater Pollution Control Federation, 57(11), 1055-1061.

Frank, J. E., \& Falconer, M. K. (1990). The measurement of infrastructure capacity: theory, data structures, and analytics. Computers Environment and Urban Systems, 14(4), 283-297. http://dx.doi.org/10.1016/0198-9715(90)90003-C

Gao, S. Y., \& Johnston, R. A. (2004). California general plan map. Sacramento, California: California Resources Agency.

Gao, S. Y., \& Walker, T. (2005). UPlan land use model calibration: Working report. Delaware Valley Regional Planning Commission.

GeoLytics. (2001). CensusCD: 2000 Blocks. East Brunswick, New Jersey: Author.

GeoLytics. (2006). CensusCD: 1990 Long Form in 2000 Boundaries. East Brunswick, NJ: Author.

Gudgel, D. (2006). Stanislaus County Department of Agriculture: 2005 annual crop report Retrieved from http://www.stanag.org/ag/croprpts/croppdf/ Crop2005.pdf

Hamilton, L. (2004). The economic impact of California specialty crops - A regional perspective. San Luis Obispo, California: Cal Poly San Luis Obispo. Retrieved from http://cissc.calpoly.edu/research/ 49936FinalReport.pdf 
Heimlich, R. E., \& Anderson, W. D. (2001). Development and the urban fringe and beyond: Impacts on agriculture and rural land (No. 803). Agricultural Economic Report Economic Research Service, U.S. Department of Agriculture. Retrieved from http://www.ers.usda.gov/Publications/AER803/

Holland, R. F. (1998). Great Valley vernal pool distribution (Photorevised 1996). In C. W. Witham, E. T. Bauder, D. Belk, W. R. Ferren Jr., \& R. Ornduff (Eds.), Ecology, Conservation, and Management of Vernal Pool Ecosystems — Proceedings from a 1996 Conference (pp. 71-75). Paper presented at the California Native Plant Society, Sacramento, California. Retrieved from http://www.vernal pools.org/proceedings/holland.pdf

Huber, P. R., Thorne, J. H., Roth, N. E., \& McCoy, M. M. (2011). Assessing ecological condition, vulnerability, and restorability of a conservation network under alternative urban growth policies. Natural Areas Journal, 31, 234-245. http://dx.doi.org/10.3375/043.031.0306

Hudson, S. (2006). 2005 Annual crop report: San Joaquin County Retrieved from http://www.co.san-joaquin. ca.us/WorkArea/DownloadAsset.aspx?id $=9570$

Iacono, M., Levinson, D., \& El-Geneidy, A. (2008). Models of transportation and land use change: A guide to the territory. Journal of Planning Literature, 22(4), 323-340. http://dx.doi.org/10.1177/0885412207314010

Johnson, M. P. (2001). Environmental impacts of urban sprawl: A survey of the literature and proposed research agenda. Environment and Planning A, 33(4), 717-735. http://dx.doi.org/10.1068/a3327

Johnston, R. A., Lehmer, E., Gao, S. Y., \& Roth, N. E. (2006). UPlan Land Use Allocation Model 2.21: User's manual Information Center for the Environment, Department of Environmental Science \& Policy, University of California, Davis. Retrieved from: http://ice.ucdavis.edu/project/uplan.

Johnston, R. A., McCoy, M., Kirn, M., \& Fell, M. (2004). Streamlining the National Environmental Policy act process through cooperative local-state-federal transportation and land use planning. Energy and Environmental Concerns 2004, Transportation Research Record (pp. 135-143). Retrieved from http://trb.metapress.com/content/cn00828355385 $10 \mathrm{l} / \mathrm{p}=8 \mathrm{bfa} 5 \mathrm{f} 5 \mathrm{e} 0 \mathrm{~d} 364149 \mathrm{~b} 18 \mathrm{da} 2 \mathrm{df} 88 \mathrm{dc} 8 \mathrm{f} 17 \& \mathrm{qp}=$ $\underline{15}$

Volume 2, Issue 4 / Summer 2012
Johnston, R. A., Roth, N., \& Bjorkman, J. (2009). Adapting travel models and urban models to forecast greenhouse gasses in California. Transportation Research Record: Journal of the Transportation Research Board, 2133, 23-32. http://dx.doi.org/10.3141/2133-03

Johnston, R. A., Shabazian, D. R., \& Gao, S. Y. (2003). UPlan: A versatile urban growth model for transportation planning. Transportation Research Record: Journal of the Transportation Research Board, 1831, 202-209. http://dx.doi.org/10.3141/1831-23

Kunkel, G. W. (2006). Tulare County annual crop and livestock report: 2004 . Retrieved from http://agcomm.co.tulare.ca.us/default/index.cfm/ linkservid/A31CF4CF-F1F6-BDD5-8E14CBBB 1B43197A/showMeta/0/

Landis, J. D. (1994). The California Urban Futures Model: A new generation of metropolitan simulation models. Environment and Planning BPlanning and Design, 21(4), 399-420. http://dx.doi.org/10.1068/b210399

Lin, G. C. S., \& Ho, S. P. S. (2005). The state, land system, and land development processes in contemporary China. Annals of the Association of American Geographers, 95(2), 411-436. http://dx.doi.org/10.1111/j.14678306.2005.00467.x

McDonald, R. I. (2008). Global urbanization: Can ecologists identify a sustainable way forward? Frontiers in Ecology and the Environment, 6(2), 99-104. http://dx.doi.org/10.1890/070038

Nature Conservancy, The. (2001). TNC portfolio conservation areas for California. San Francisco, California: TNC California Regional Office.

Nelson, A. C. (1992). Preserving prime farmland in the face of urbanization: Lessons from Oregon. Journal of the American Planning Association, 58(4), 467-488. http://dx.doi.org/10.1080/01944369208975830

Niemeier, D., Bai, S., \& Handy, S. L. (2011). The impact of residential growth patterns on vehicle travel and pollutant emissions. Journal of Transport and Land Use, 4(3). http://dx.doi.org/10.5198/jtlu.v4i3.226

Niswander, T. L. (2006). Agricultural crop report: Kings County, California 2004. Retrieved from http://www.countyofkings.com/ag $\% 20$ commissio ner/Crop $\% 20$ Reports/RPT2006.pdf 
Prieto, J. (2006). 2005 annual crop report. Retrieved from http://www.co.fresno.ca.us/Department Page aspx?id $=6266$

Randall, A. (2007). A consistent valuation and pricing framework for non-commodity outputs: Progress and prospects. Agriculture, Ecosystems \& Environment, 120(1), 21-30.

http://dx.doi.org/10.1016/j.agee.2006.03.036

Richardson, H. W., \& Bae, C.-H. C. (Eds.). (2004). Urban sprawl in Western Europe and the United States. Burlington, Vermont: Ashgate Publishing Company.

Robinson, D. A. (2006). Annual report of agriculture 2004. Retrieved from http://www.co.merced.ca.us/ Archive.aspx?ADID $=241$

Rolan, R. J. (2006). Madera County Agricultural Crop Report: 2004. Retrieved from http://madera-county.com/ index.php/publications/crop-reports?download = 483:madera-county-2004-agricultural-crop-report

Sacramento Area Council of Governments. (2007). Preferred blueprint alternative. Sacramento, California: Author. Retrieved from http://www.sacregionblueprint.org/sacregion blueprint/the project/BP Insert JUN 2007.pdf

Sandhu, H. S., Wratten, S. D., Cullen, R., \& Case, B. (2008). The future of farming: The value of ecosystem services in conventional and organic arable land: An experimental approach. Ecological Economics, 64, 835-848. http://dx.doi.org/10.1016/j.ecolecon.2007.05.007

Sarkar, M. (2011). How American homes vary by the year they were built (No. Working Paper 2011-18). Washington, D.C.: U.S. Census Bureau. Retrieved from http://www.census.gov/hhes/www/ housing/housing patterns/pdf/Housing $\% 20$ by \%20Year $\% 20$ Built.pdf

Schwarzenegger, A. (2005). Executive Order S-5-05. Executive Department, State of California.

Sokolow, A. D., Hammond, S. V., Norton, M., \& Schmidt, E. E. (2010). California communities deal with conflict and adjustment at the urbanagricultural edge. California Agriculture, 64, 121-128. http://dx.doi.org/10.3733/ca.v064n03p121

State of California. (2008a). California Food and Agriculture Code: Food and Agriculture.

State of California. (2008b). California Government Code: Government Code.

Tan, R., Beckmann, V., van den Berg, L., \& Qu, F. (2009). Governing farmland conversion: Comparing China with the Netherlands and
Germany. Land Use, 26(4), 961-974.

http://dx.doi.org/10.1016/j.landusepol. $\underline{2008.11 .009}$

Theobald, D. M. (2001). Land-use dynamics beyond the American urban fringes. Geographical Review, 91(3), 544-564. http://dx.doi.org/10.2307/3594740

Thomas, J. K., \& Howell, F. M. (2003). Metropolitan proximity and US agricultural productivity, 19781997. Rural Sociology, 68(3), 366-386.

http://dx.doi.org/10.1111/j.15490831.2003.tb00142.x

U.S. Census Bureau. (2000a). Population estimates: Historical data, 1980s national tables. Washington, D.C.: U.S. Census Bureau. Retrieved from http://www.census.gov/popest/data/historical/ index.html

U.S. Census Bureau. (2000b). Population estimates: Historical data, 1990s national tables. Washington, D.C.: U.S. Census Bureau. Retrieved from http://www.census.gov/popest/data/historical/ 1990s/index.html

U.S. Census Bureau. (2010). Population estimates: Historical data, 1990s national tables. Washington, D.C.: U.S. Census Bureau. Retrieved from http://www.census.gov/popest/data/historical/ 2000s/vintage_2009/index.html

U.S. Department of Agriculture. (2009a). 2007 national resources inventory: Summary report. Natural Resources Conservation Service, Washington, DC, and Center for Survey Statistics and Methodology, Iowa State University, Ames, Iowa. Retrieved from http://www.nrcs.usda.gov/Internet/FSE DOCUMENTS//stelprdb1041379.pdf

U.S. Department of Agriculture. (2009b). 2007 census of agriculture. Washington, D.C.: U.S. Department of Agriculture. Retrieved from http://www.agcensus.usda.gov/Publications/ 2007/Full Report/

U.S. Geological Survey. (2004a). National bydrology dataset 100k waterbodies. Washington D.C.: United States Geological Survey.

U.S. Geological Survey. (2004b). National bydrology dataset 100k flowlines. Washington D.C.: United States Geological Survey.

Walker, T., Gao, S., \& Johnston, R. (2007). UPlan: Geographic Information System as a Framework for Integrated Land Use Planning Model. Transportation Research Record: Journal of the Transportation Research Board, 1994, 117-127. http://dx.doi.org/10.3141/1994-16 